\title{
TWO ENFANTS TERRIBLES IN DUTCH EXILE: THE EXILIC POSTURE OF JAROSLAV HUTKA AND IVAN LANDSMANN
}

\author{
LUCIE SEDLÁČKOVÁ
}

\begin{abstract}
This article addresses the topic of authorial posture (as defined by Jérôme Meizoz), in particular the exilic posture. Some exiled authors, listed as examples, or prototypes of that posture, were able to achieve a stable place in the Dutch literary or cultural field. This text shows, however, that some exiled authors or artists were not endowed with the crucial qualities and abilities, and it investigates what kind of qualities and abilities they missed. The Czechs Jaroslav Hutka and Ivan Landsmann spent a part of their lives in exile in the Netherlands, where they also created literary texts. The songwriter, poet and prosaist Hutka and the novelist Landsmann did acquire a firm position in the Czech cultural and literary field without really penetrating the Dutch one. This article examines the extent to which they represented the exilic posture, describes it in more detail, and provides more fitting designations. By doing so, it answers the question why these two authors did not or could not acquire an established position in the Dutch cultural field during their exile period.
\end{abstract}

Keywords: authorial posture; Jérôme Meizoz; Jaroslav Hutka, Ivan Landsmann; exile; the Netherlands

\section{Introduction}

In the second half of the twentieth century, the Netherlands accepted hundreds of thousands of refugees. In the same period, hundreds of thousands of Czechoslovaks found political exile abroad. These two groups had, however, a rather small intersection. ${ }^{1}$ Miroslav Kabela (1938-2011) belonged to that small group: a psychiatrist, who had escaped from Czechoslovakia via Austria to the Netherlands in 1956, where he was later helping other refugees from all over the world. He explained the relatively low presence of Czechoslovak exiles in the Netherlands by the combination of several factors: unknown language, inclement weather, oppressive Calvinism, different perception of friendship, excessive seriousness and rigidness, lack of emotions and sentiment. According to him,

1 Most likely, there were only a few thousand Czechoslovak immigrants in the Netherlands. The Czech Ministry of Foreign Affairs puts the number of emigrants in the Netherlands at 3,000. https://www .mzv.cz/file/1556132/Krajane_v_Nizozemsku.doc. Last access 29 March 2021. 
Czech people are more compatible with Belgians, Bavarian Germans, Austrians, Italians, or the French (Kabela in Thomassen 49).

The relatively small group of Czechoslovaks who found themselves in Dutch exile after the 1948 communist coup and the 1968 Warsaw Pact invasion included a number of personalities who were able to start up or continue a successful career in the host country, such as the poet and translator Jana Beranová, the historian Zdeněk Dittrich, the writer and translator Verra Ebels-Dolanová, the photographer Helena van der Kraan, and the choreographer Jiří Kylián. ${ }^{2}$ The exiles were usually politically aware people, and, inherently, highly educated intellectuals. This has been affirmed by the immigrant, psychologist and university professor Jiří Diamant: according to him, most of the Czechs adapted themselves well in the Netherlands, although the Dutch have such a "peculiar language" that even with a university degree you feel "semi-literate" there in the beginning (Diamant in Štráfeldová). ${ }^{3}$

For some exiles, especially those who emigrated at a young age, language was not such a dramatic barrier. My article on the poet Jana Beranová and the novelist Jan Stavinoha proved that these authors of Czech origin had achieved their positions in the Dutch literary field without gaining a similar position in the Czech one. It also showed that neither of them wanted to identify with the label of an intercultural author and accept an exilic posture. Instead, they wanted to be regarded as fully-fledged Dutch writers (Sedláčková 48).

On the other hand, there are exiles who have based their positions in the literary field on their role of a refugee and a cultural ambassador. The Dutch author of Iranian origin Kader Abdolah has become a prototype of the exilic posture (Bongers; Van Voorst) and, at the same time, a public intellectual with a clear mission (Dynarowicz). Abdolah, who has become more popular with readers than an average native Dutch writer, is, however, rather an exceptional case. It is not the aim of this article to manifest Abdolah's uniqueness. On the contrary, it intends to demonstrate that some exiled authors and artists were not endowed with qualities and abilities crucial to achieve a position in the Dutch cultural or literary field, and it investigates what qualities and abilities these are. In the same period as Beranová and Stavinoha, two other Czechs, Jaroslav Hutka and Ivan Landsmann, wrote their texts in the Netherlands. Hutka and Landsmann did acquire a firm position in the Czech cultural and literary field without really penetrating the Dutch one. This article examines the extent to which they represented the exilic posture, describes it in more detail, and gives more fitting designations. By doing so, it also answers the question why these two authors did not or could not get an established position in the Dutch cultural field during their exile period.

\section{The concept of authorial posture}

After literary scholars declared the author dead and research moved to the text itself, to the context or reception studies, interest in the author's person has recently experi-

2 See Praagse Lente - Pražské jaro Revisited 68: 107-150.

3 All quotations from Czech and Dutch sources were translated by the author of this article. 
enced a revival, especially in the French-speaking countries, and some other parts of the Western scholarly world. Post-Bourdieu researchers (such as Gisèle Sapiro, Pascale Casanova, Bernard Lahir, Jérôme Meizoz) have adopted some traditional concepts, such as habitus, position, and trajectory, and formulated various forms of the new sociology of literature (Šebek 114-115). As this article investigates the exile period of the songwriter and poet Hutka and the prose writer Landsmann, two rather peculiar personalities of the Czech cultural field, it will be purposeful to include both the concept of habitus ${ }^{4}$ (i.e., to consider what kind of environment they came from and what cultural taste they had) and the concept of trajectory ${ }^{5}$. In both cases, the analysis will be based on the belief that biographical data are linked not only to the habitus and trajectory but also to the author's image, as it is being formed both by others (especially by the media and critics) and by himself in various ego-documents. Therefore, it will be useful to employ Jérôme Meizoz's analysis and his concept of authorial posture, which includes both the public (self-)presentation of the author and his discourse (particularly non-fiction texts, but possibly also autobiographical fiction).

Meizoz applied his own theory to the classical case of Jean-Jacques Rousseau. By doing so, he demonstrated two basic components of posture. Firstly, it is behaviour: "the author's public presentation of self, such as media appearance, the discourse of literary awards, biographical notes, response to reviews, and so on: clothes, hairstyle, certain gestures, a look, accessories [...]". The second component is discourse (according to Meizoz, similar to ethos in rhetoric): "the textual self-image offered by the enunciator" (Meizoz 85). These categories are not to be analysed as isolated elements, since there is a "correlation between the author's enunciative ethos, his position in the literary field, and the audience he attempts to attract" (Meizoz 85).

The concept of posture has been recently employed by a number of scholars in the Dutch Literature and Dutch Studies. ${ }^{6}$ It was, for instance, used in the publication Schrijverstypen (Types of Authors, 2016), in which Dutch nineteenth- and twentieth-century writers were analysed. This research confirms Meizoz's proposition that it is possible to work with certain recurrent types of authors, such as the romantic writer, the socialist poet, the traveller, the cosmopolitan, or the exiled writer (Van Boven and Verstraten 10). This article gives, however, a more detailed image of two men who were, certainly, exile writers, but not prototypical ones, since they also carried certain specific qualities that made them unable to take a position in the literary (or cultural) field.

4 Habitus, as developed by Bourdieu, is a set of constant dispositions of the actors, acquired in their history. These are co-created by their social class and group, and have a stratifying effect. They make the actor behave in a certain way and take up certain positions and avoid other positions in the cultural field. Habitus is what the actors bring with them when entering the cultural/literary field. (See Bourdieu 1977: 78-84 and Šebek 29-31).

5 After entering the cultural/literary field, the authors adopt certain positions, complying with their habitus (and at the same time, the habitus may change due to the field). The movement in the field is labelled as trajectory. (See Bourdieu 2010: 339-343 and Šebek 31)

6 See, for instance: Dorleijn 2007; Rovers 2008; Dorleijn, Grüttemeier and Korthals Altes 2010; Bongers 2011; Rovers 2012; Ham 2015; Bossaert 2020. 


\section{Exiles Hutka and Landsmann}

The life stories of exile authors create a specific subject matter, suitable for literary interpretation (as they have a lot of "usable past"), particularly with a strong moral message. They are often mediators between two (or more) cultures; and they have to adopt specific modes of writing and publishing: writing in various languages, including non-native languages; samizdat publication; writing as autotherapy; writing without publishing ("writing for the drawer" as it is called in Slavic languages, i.e., without a reading public) and delayed publishing. For exiled authors, autobiographical elements are of crucial importance.

This holds true for both Hutka and Landsmann, even though their positions in the Czech cultural/literary field differ significantly: Hutka was a popular songwriter since the 1960s and later also a poet, prose writer and columnist, whereas Landsmann worked in a coal mine at that time and became an extraordinary phenomenon of the Czech literary scene only in the late 1990s. Nevertheless, the fortunes and misfortunes of Hutka and Landsmann in exile are inseparably intertwined. In Rotterdam, these two Moravians became best friends; moreover, Landsmann would have never become a writer without Hutka's support. Therefore, it is meaningful to investigate their postures together in this article, as their literary discourses co-create each other's image.

\section{Hutka: biographical background}

To show what position Hutka occupied in the Czech cultural field before emigration, it is important to consider his biographical background and habitus. Jaroslav Hutka (born 1947 in Olomouc) was of middle-class origin, his father being a furniture shopkeeper. As the father was considered a capitalist and a bourgeois, the family was persecuted after the 1948 communist coup and forced to move several times and to live in humiliating circumstances during Jaroslav's childhood. Hutka himself characterizes his origin as "petit bourgeois", with culture being an essential part of their life (for example, his parents always had theatre season tickets; his father read aloud for the family), but their financial situation was "proletarian" (Hutka in Čermák 26). Hutka experienced communist victimization at an early age, which led him to adopting a position against the regime and its official culture. Another important stimulus was provided by the secondary school of decorative arts in Prague: he was lucky enough to be admitted to study there, despite his origin. Thanks to his studies (which he did not finish because of his rebelliousness), he could enter the artistic scene and Prague's alternative culture.

In the 1994 book of interviews Pravděpodobné vzdálenosti (Probable Distances), Hutka told his life story thus far. The titles of the book's individual sections fittingly describe Hutka's trajectory in the Czech cultural field: "Hooligan and beatnik (1947-1978)", "Mystic, folk singer, dissident (1970-1978)", "Emigrant (1978-1989)", "Singer (1989-1994)".

In the first period he was regarded as a hooligan due to his long hair: an image that would characterize him and complicate his life. ${ }^{7} \mathrm{He}$ did not have a regular job, was often

7 In Czechoslovakia, it was illegal for men to have long hair. Such individuals were, for instance, excluded from public transport or public premises. 
on the breadline, started to write his own songs and perform with friends (the first performances took place on Charles Bridge and attracted quite a large audience). After 1968, he started to perform by himself: the texts were more important to him than the music (acoustic guitar in his case). He called his songs from that period educational and mystical (Hutka in Čermák 55-56).

At the turn of the 1960s and 1970s he devoted himself to astrology, spiritualism, and he also discovered Moravian folk songs, which he started to play at his concerts. He went on writing his own songs: critical as well as humorous. He performed in clubs and at folk festivals (his concerts were often camouflaged as other events). The 1970s brought him the most popularity, but the regime prevented him from playing in the media: one of his LPs became the record of the year 1977, but it was forbidden to mention his name. At that time, Hutka was in touch with the dissidents around Václav Havel and Charter 77 which he signed. The secret police put him under surveillance and interrogated him; he was accused of illegal entrepreneurship (according to their expert opinion, Hutka was not an artist). At that time, he began to fear imprisonment, and after the pressure from his wife, student Daniela Hutková, he decided to emigrate, which was acceptable even for the secret police.

His emigration took place in a relatively calm way: in October 1978 Hutka and his wife loaded up their Škoda, including a typewriter with Czech diacritics, took a photo with their parents and friends, and headed for the West. They had no special relation to the Netherlands: the country had been recommended by friends. They were able to obtain political asylum unusually quickly, thanks to their friendship with a social-democratic MP, Hans Kombrink (whom they had got to know during his holiday in Bohemia). They started living in a modest attic flat in Rotterdam, in the infamous district of Delfshaven. Hutka was unemployed, living on benefits; his wife studied Slavic languages in Leiden. After the Velvet Revolution, Hutka returned to Prague. (Čermák 64-160)

Before emigrating, Hutka belonged to the top of alternative folk music in the Czech cultural field, performing in a semi-underground scene (his concerts were tolerated, but he did not exist in the media). He wrote almost two hundred songs, seven collections of poems, two books of children rhymes, three novellas and several columns. ${ }^{8}$ Additionally, he released two LPs (1974 and 1976). However, most of his literary texts (except for the children rhymes) were published only after his return from exile.

\section{Landsmann: biographical background}

While Hutka was given a standing ovation at his concerts, his future friend Landsmann went down into the North-Moravian coal mines. Ivan Landsmann (born in 1949 in Nový Jičín, died in 2017 in Prague) was of a lower-class, "proletarian" origin. Both parents worked first in heavy manufacturing, later in coal mining (his father was a mechanic and mother was a labourer). During Ivan's childhood, his father spent two years in prison for complicity in theft and later left the family. For Ivan, these were traumatic and stigmatizing experiences: he lost interest in school and did not even finish an apprenticeship. After

8 Information from his personal website www.hutka.cz. Last access: 31 March 2021. 
the 1968 invasion, he was idling and got a suspended sentence for "parasitism". 9 After the military service, Landsmann got married and started to work in a black coal mine, in which he persisted for fifteen years and achieved the position of foreman. He was in touch only with his colleagues and their families, had no intellectual hobbies, and spent his spare time only in pubs or in the mountains. He had anti-communist opinions, refused to enter the communist party, but he could not complain about his economic situation (miners' wages were high above the average). He was longing to go to the West but was not a dissident at all. Hutka (in Čermák 140) said about his motivation: "He wanted to escape: from his work, the communists, his mean and materialistic wife, who forced him to take weekend shifts so that she could buy things [...]". One of Landsmann's brothers had emigrated to Canada, where he ran a car repair shop. After many attempts, Ivan was finally able to visit him in 1985, intending to stay at his place. However, the brothers had an argument and Ivan applied for political asylum in the Netherlands, during a stopover at the Amsterdam airport. Without the knowledge of English or Dutch, he was hanging around Schiphol, Amsterdam and Rotterdam for several weeks, in search of Czechs who would help him. In this way he found Jaroslav Hutka, who started to look after him as if he were a small helpless child. Landsmann got his political asylum only in 1989: before and after that, he mostly lived on benefits, spending lots of money on alcohol. After the 1989 revolution he wanted to return to Czechoslovakia, but he would find neither shelter nor work as he had lost Czech citizenship due to emigration. He remained in exile until 2000, when he could move in with his new partner in Prague. ${ }^{10}$

When Landsmann emigrated, he did not occupy any position in the literary field at all. His habitus corresponded with his lower-class origin. In the interviews from a later period, he never spoke about literary or cultural inspiration whatsoever. He did not read books or newspapers, did not listen to radio plays, and just sometimes watched a movie, as he said in an interview after returning to Czechia (Landsmann in Goldmann 7). Based on his autobiographical texts, this was also the case before and during his exile. At the time he started to write in the Netherlands, he could be figuratively labelled as "tabula rasa".

The above-mentioned facts show how much these two personalities were influenced by their social origin and their environment. Although neither of them finished secondary school and both had anti-communist opinions, Hutka grew up in a family that, in spite of financial problems, led a cultural life, and he was able to achieve a position in the cultural field thanks to an arts school and artistic friends. By contrast, Landsmann led a life of a real proletarian and had no contact with the cultural scene. It is surprising that Landsmann did not know at first that Hutka was a popular Czech songwriter when looking for him in Rotterdam.

9 During the communist regime, the term "parasitism" ("příživnictví") was used for unemployment. It was a criminal offence at that time. Everyone was obliged to have a job.

10 Information from the Memory of Nations project. https://www.pametnaroda.cz/cs/landsmann-ivan-1949. Last access: 31 March 2021. 


\section{Hutka in Dutch exile: behaviour}

When looking at Hutka's portraits from the time before emigration, during his Dutch exile (1978-1989) and the present, it will strike you how much he sticks to his image. At all times, he has been faithful to a hippie-like appearance: long, naturally wavy hair, a beard, John Lennon glasses, an oversize sweater and jeans. ${ }^{11}$ His usual accessories are: an acoustic guitar, a glass of beer or wine, and a cigarette. He stuck to this beatnik/hippie image during his exile as well, as was regularly mentioned by the Dutch press. In 1982, he was described as "Berkeley student from the 1960s" (De Jong 1982: 17); in 1991, Mulder (16) mentioned that Hutka had never given up his long hair and returned from exile in the same jeans and slouchy sweater in which he emigrated. This image was further reinforced by the photographs that accompanied articles about Hutka in the Dutch press. Moreover, Hutka got another constant attribute in those articles, namely "a Rotterdam attic flat" (Jeensma and Wieringa 16), or even "an attic room in a gloomy district of Rotterdam" (De Jong 1984: 20). This image of a poor intellectual and an anonymous refugee was usually contrasted with his past fame in Czechoslovakia: he was designated not only with neutral terms as "singer", "poet", "singer-writer", "songwriter" and "protest singer", but also with more expressive ones as "bard", "national bard", "popular Prague troubadour" and "folk music star". The articles referred to his past success and popularity in contrast with his anonymous present. As to his music, he was most often compared to Bob Dylan;12 and he used this comparison himself in a 1988 interview: "I was [...] you could say, sort of a Czech Bob Dylan, or Donovan" (Middelburg 6). Among his Dutch fellows, he was mostly compared to (young) Boudewijn de Groot; and sometimes also to Jaap Fischer, Ramses Shaffy, and Herman van Veen. They were singers approximately of the same generation as Hutka (or a bit older) who got famous in the 1960s and were mostly associated with that period. Thus, we can read between the lines that Hutka principally resembled a past, out-of-date culture.

In general, Hutka appeared in the Dutch media regularly both during his exile and after it (especially during the Velvet Revolution). One article about him appeared even before his arrival (in De Volkskrant, 18 Nov. 1977), which related to the persecution of Czechoslovak artists and an open letter that Hutka had sent to the French chanson singer Yves Montand. Another mention about Hutka, this time in all major daily papers (NRC Handelsblad, Het Parool, Trouw, De Volkskrant, 27 and 28 Oct. 1978), corresponds with his emigration to the Netherlands: Hutka and his wife had brought an open letter of the signatories of Charter 77, who criticized the attitude of the delegation of the Netherlands Union of Journalists (Nederlandse Vereniging van Journalisten, NVJ). The following article in NRC Handelsblad (Salomonson 3) paid attention to Hutka himself and informed about his emigration to the Netherlands. The articles from the beginning of the 1980s presented Hutka's anonymous-refugee-in-an-attic-room-image. Stress was laid on his refugee identity, anonymity in the host country, uprootedness, loneliness, and language loss. At that time (1982), Hutka also announced his first LP record in Dutch, which he would release at his own expense with the help of friends since he would not accept the

11 See his portraits in the photo gallery from 1966 till 2019 on his website www.hutka.cz.

12 E.g., in: "Liedjeszanger Jaroslav Hutka: 'Leven in Oosten of Westen? Mensen zijn de besten!' Het vrije volk 27 Dec. 1980: 3. 
terms of commercial record companies (De Jong 1982: 17). ${ }^{13}$ Here, one could notice several other features that co-created his exilic posture: stubbornness, intransigence, tenacity, and craving for independence. In that period, Hutka performed only in small Dutch towns and villages and at small events, where he was mostly invited as a refugee (especially for events by Amnesty International); he sometimes published short texts (columns, short stories) in a Dutch translation (again related to his role of a refugee, e.g., in magazine WAR).

Hutka made a small breakthrough in 1984, when his first and last LP record in Dutch, Hier is mijn thuis, came out. ${ }^{14}$ Het vrije volk and Het Parool brought more substantial articles; De Volkskrant published a positive review (in the same section where U2 and David Bowie were reviewed). The comments and Hutka's own words raised hopes for a new beginning. Hutka was happy that he had finally found a good translator into Dutch: Gert Helmer, a university professor in Nijmegen, whose brother Sjef published a bulletin on Charter 77. Thanks to that, Hutka would, for the first time, perform in a big city (Rotterdam); he was not that "displaced and sulky individual" anymore (Verhulst 21). After he had visited Czech immigrant communities in other countries, he realized that he did not want to be an immigrant anymore, and that is why he was trying to achieve a place in the Dutch cultural life (van Veen 7). That period can be characterized as Hutka's effort to integrate into the Dutch cultural field. He hardly wrote in Czech (as he was not able to write without an audience). He considered the Dutch language the biggest hindrance in his Dutch career. According to him, it was hardly possible to master it: the classes provided by the authorities were unsatisfactory, as well as the learning methods. Nevertheless, later interviews show that his wife Daniela spoke Dutch well at that time, which increased his frustration even more. Hutka spoke neither English nor German upon his arrival to the Netherlands; he learned all the languages simultaneously. He regarded attending Dutch classes "humiliating" for "an adult man", as he had to go to a "sort of pre-school for toddlers" (Hutka in Čermák 130). This can be seen as yet another factor hindering him from entering the Dutch literary field: he wanted to write existential and critical texts in a language that he refused to learn from the trivial beginning (compare, e.g., the approach of Kader Abdolah, who did not hesitate to publish his first short stories in very simple Dutch). Besides, Hutka blamed the Dutch themselves for having no respect for their language. According to him, they also dissuaded him from learning it.

Other mentions about Hutka appeared in the Dutch press in connection with anniversaries (ten years of Charter 77; twenty years after the 1968 invasion). In 1988, one can hear his pessimistic self again. He considered his life a failure, due to his divorce, living on public benefits, interrupted career, and his Dutch LP being a "flop" (Middelburg 6). At that time, he parted with Holland and was gradually moving to his new partner in Cologne. He had considered Germany a better exile destination for a long time as there are: "poets, books, theatre and romantic people"; Czechs mostly integrated without prob-

13 Other sources, such as his own texts (Hutka 2012), show that he was refused by all the record companies he had addressed.

14 The title is a literal translation of his older song „Tady domov mám“ (Here Is My Home, 1974). It was his answer to the question asked in the Czech national anthem. In Dutch the text got an additional meaning. Besides, the composer of the anthem, František Škroup (1801-1862) was buried in Rotterdam. 
lems there (Hutka in Čermák 136). It is a fact that there were much more Czech immigrants in Germany, which meant a relatively large potential audience. For Hutka, the lack of audience turned out to be even worse than the language barrier. He stated that culture in the Netherlands was a mere superstructure (as Marx put it), whereas it was a basic necessity of life for the Czechs. Hutka considered the Dutch a traditional nation of traders. The only Dutch writer whom Hutka repeatedly mentioned and considered passionate was the nineteenth-century prosaist Multatuli (Hutka in Jeensma and Wiersinga 16).

Later articles about Hutka in the Dutch press date from the time of the Velvet Revolution. Only a week after its beginning, Hutka flew from Germany to Prague without knowing whether he would be let in without permission. He was welcomed by a mass of his fans and during the demonstrations he sang for half a million people. In the Dutch reports, one can feel the greatest pride that Hutka had chosen the Netherlands for his exile.

In the long run, one can see that Hutka's image in the Netherlands was not so idealistic. As described by Thomassen (49): Hutka was a well-known "grumbler" ("kankeraar" in Dutch) among Czech immigrants, not willing to work. Mulder (16) stated the same about Hutka's behaviour: a stubborn man, who refused to choose a different job (although he had studied graphic design), who revelled in his personal tragedy, who sought an audience in vain and became more and more isolated as he could not find any allies in the Dutch cultural field. Only his truest fans (mostly Czech immigrants) bought his selfmade audio tapes, out of pity or nostalgia. Hutka gradually became a fossil of his own past (which he must have realized, as he called his own publishing company Fosil). The free West was hostile to him, but he did not know any compromise and refused to adapt (both economically and culturally). He summarized his idiosyncratic exile position with these words: "They listened to me, with my bad accent, patiently. But I wish they had known how much patience I had with them!” (Hutka in Mulder 16).

\section{Landsmann in Dutch exile: behaviour}

Whereas there are numerous records about Hutka's exile period, Landsmann lived in exile almost anonymously. He spoke about his (mis)fortunes in public only after his return to Czechia, when he was already a recognized writer (e.g., in the Memory of Nations project, or for the Czech Television). His life story was, however, so bizarre that Hutka captured it in several of his texts, giving us a rather clear image. As described above, the coal miner Ivan Landsmann, without knowledge of any western language, found himself in Holland only by accident and first spent some weeks in the pubs of Amsterdam and Rotterdam. He slept in parks and fields until Hutka rescued him (Landsmann had found his address in a telephone book and rang his door for several weeks until Hutka came back from holidays). This kind of naivety, helplessness and reliance on others would characterize Landsmann's authorial posture. Hutka labelled him a "Bag of Potatoes” for his absolute passivity (Hutka in Čermák 142). While Landsmann was waiting for political asylum, he treated his depression with alcohol, and Hutka feared he would take his own life. Therefore, he advised him to write his memoirs as a therapy. Landsmann wrote hundreds of pages full of recollections from his life as a miner and about his emi- 
gration. Hutka was fascinated by his authentic narrative skills and sent the manuscript (finished in June 1986) to Canada to the well-known and influential Czech exile writer Josef Škvorecký. The latter, subsequently, sent a testimonial to the Dutch authorities, in which he designated Landsmann a recognized Czech author. That helped Landsmann in the end to gain political asylum (in 1989). The manuscript was not, however, published by Škvorecký in his Canadian publishing house; it came out as late as in 1999 as Landsmann's debut novel Pestré vrstvy (Colourful Layers) in the Prague publishing house Torst.

Judging by photos and certain autobiographical texts we can presume that Landsmann was a common, inconspicuous person, but for women quite an attractive man (with his dark hair and dark, mesmeric eyes). He arrived in the Netherlands with a single piece of luggage, and he hardly bought new clothes later. Although he learned English and Dutch even with more difficulty than Hutka, it was much easier for him to find friends - or at least - buddies with whom he could drink and enjoy himself. Landsmann complied with the image of a simple proletarian, able to arouse affection, or sympathy, and gifted with a natural palaverous talent.

Landsmann's exile did not end in 1989. In the 1990s he stayed in the Netherlands and got Dutch citizenship. He lived mostly on public benefits, but sometimes tried to find a job. That was complicated by health problems (vasoneurosis, a consequence of his miner's past). Although he wanted to return in the 1990s, he could not as he had lost his Czech citizenship and claim to pensions. In the second part of his exile, he continued writing without publishing: his texts were later published as the novels Fotr (My Old Man, 2000) and Vězení na svobodě (Jail in Freedom, 2002). His naivety and complete ignorance became evident when he was entering the Czech literary field. In the late 1990s he was approached by the Prague publishing house Torst with the proposal to publish his three books. Landsmann subsequently signed extremely unfavourable contracts. The debut Pestré vrstvy became a success and was even voted the book of the year (1999) by the readers of the quality paper Lidové noviny. However, Landsmann could not return to Czechia until Lucie Váchová, his keen reader and prospective wife, took charge of him. His Dutch exile ended in 2000, when he moved to her place in Prague. In Prague he was helpless for a long time, took demeaning jobs, like a security guard in a bookshop until his new wife succeeded in claiming a pension for him. He published another two novels but not with Torst. At that time, he already achieved a stable place in the Czech literary field, gave author readings and interviews, appeared in TV programmes, and his first novel was adopted for theatre by Petr Bezruč Company in Ostrava. He died at the age of sixty-eight. ${ }^{15}$

Although three of his novels were written and, partly, set in Holland, he did not reach the Dutch literary field. In an interview, Landsmann mentioned that Pestré vrstvy was intended for translation, but the Dutch translator gave it up because Landsmann "used words that cannot be translated" (Landsmann in the Memory of Nations project). In other words, that was due to Landsmann's inimitable style (a combination of miners' jargon, incomprehensible even to Czech native speakers, and a North-Moravian dialect).

His posture can be characterized as a proletarian with a natural narrative talent, entering the literary field as a tabula rasa, and resembling an enfant terrible with his lifestyle.

15 The biographical information about Landsmann is mostly based on the Memory of Nations project. 


\section{Hutka in Dutch exile: discourse}

As stated above, the other component of posture is discourse (or ethos). It is the image that can be deduced from the author's texts, especially non-fiction, or possibly also fiction if it is (strongly) autobiographical. Meizoz himself adheres to an interdisciplinary approach, as it is not possible to analyse the components separately. Dorleijn (2007) has shown that the intermedial play between literature and music can play a role in the position-taking of (especially) literary authors. Therefore, Hutka's song lyrics from the exile period are also included here because they can be considered as a kind of self-presentation. Hutka himself regards his song lyrics as a kind of poetry. ${ }^{16}$

During his exile, Hutka wrote mainly columns, poetry and song lyrics, and also diary-like prose, ${ }^{17}$ short stories, and (fictional) letters. ${ }^{18}$ During his concerts he also sang his older songs (both in Czech - for Czech immigrant communities outside the Netherlands - and in English, German and Dutch). In the Netherlands, he released one LP record with Dutch lyrics (Hier is mijn thuis, Paladyn Rotterdam, 1984).

His columns (in Czech) were an important medium of his opinions as they were in demand in exile magazines, for instance in West Germany. His texts could therefore reach a limited audience of Czech emigrants all over the Western world (from the USA to Australia). Some of his columns were, however, refused by editors, due to Hutka's critical opinions on Czech history, culture and emigrant attitudes. ${ }^{19}$

In the columns, Hutka deliberately took a position in the tradition of Czech banishment, which he relates to Czech Protestantism, especially in the period after 1620 (defeat of Czech protestants). "Comenius finished his pilgrimage where I start my own," Hutka wrote in 1978 upon in his arrival to the Netherlands (Hutka 2009: 85). The first substantial conflict with the emigrant community was sparked by his 1979 column "Požár v bazaru" (A Fire in a Junk Shop), in which he presented his critical view of Czech history and the establishing of the Czechoslovak state. Czechoslovakia was a multi-national country, but according to Hutka, it was based on aggressive Czechoslovak nationalism. He was particularly critical regarding the expulsion of Germans from Czechoslovakia after World War II (the expulsion was then, and also later, a taboo): the Czechs were, according to him, guilty of the same racism as the German Reich. Hutka suggested that it was necessary to start with a fire in our junk shop, by which he meant the removal of fakes in the national identity. With these decided opinions, Hutka deliberately made a lot of enemies among Czech emigrants, and therefore, his exile audience was not as large as he had wished. He wrote his later columns in the same spirit.

His notion of the free West was not idealized either. He criticized it particularly for its passivity as it was afraid of any conflicts, and therefore, it did not help dissidents in

16 Hutka's poems and song lyrics differ mainly formally: poems are written in free verse, whereas songs have regular rhythm and rhyme.

17 The texts Cesta do království (The Way to the Kingdom, describing the period preceding their emigration and shortly after arrival in the Netherlands) and Dvouseta (Two Hundred, a novella dedicated to his wife Daniela) have the form of a diary.

18 Dopisy Ivanovi (Letters to Ivan, written in 1985, published in 2012) were fictive letters to the Czech dissident-writer Ivan Klíma.

19 Columns from the period between 1977 and 1989 were published as Požár v bazaru (A Fire in a Junk Shop) by Hutka at his own expense in Rotterdam. A complete book of his columns came out in 2009. 
the East sufficiently. He described the mutual ignorance and incomprehension between the East and the West as disastrous. Exiles in the West were allowed to write whatever they wanted but nobody listened to them. This was linked, fundamentally, to his creative crisis: he was not able to write if he could not see an audience in front of him. He did not want to write for the exiles (due to their narrow-mindedness, puritanism, old-fashioned moralizing) and could not write for anyone else as he was not able to formulate his thoughts in any other language. Therefore, he was not better off than Václav Havel in Prague, who could not see his plays on stage as they were staged only in the West. It seems as if Hutka felt as a dissident even in the West since he could not write freely, due to a lack of audience and the language barrier. In addition, Hutka did not look for allies in the Dutch literary field and stayed a lone wolf. Although the Dutch press shows that Hutka sometimes performed at cultural events, especially those relating to immigrant topics, he did not establish any literary relationships. He was, for instance, often invited together with Jana Beranová, the Rotterdam poet of Czech origin. ${ }^{20}$ According to Hutka, they did not like each other since she had established a "monopoly over Czechoslovakia", and he complicated her "business" as poetry in the Netherlands was also subject to "trade laws" (Hutka 2012: 312-313). Hutka himself called Landsmann his only friend in exile. In his columns he did not name any Dutch writer or poet. And he did not feel like integrating in the Dutch immigrant community.

Hutka's exile poetry is also strongly autobiographical: four parts from the collection Koryta krve (Blood Streams, 1996), which were written in 1983-1984, 1985, 1987 and 1988. Judging by the motifs, Hutka was mostly inspired by important personal events (existential or partner crises) and his summer travels to southern Europe (France, Spain). A frequent motif is the language: the inability to communicate, related to isolation. This is sometimes contrasted with the figure of a dynamic wife, who despises him for his powerlessness, weakness and failures. Hutka is sometimes even pathetic or decadent, or takes on the image of a poète maudit. He cannot find satisfaction in poetry as he lacks an audience. For Hutka, the autotherapy is not sufficient: he writes out of fear of "vanishing" (Hutka 1996: 63). The emigration itself is depicted as a split of oneself: the body finds itself in Rotterdam, but the soul is still on the way; they are gradually merging with great difficulty. A recurring motif is a fossil, to which Hutka compares himself for his stagnating in the past. His host country is mentioned in the poems less than France and Spain, but in a poem dedicated to Rotterdam, he feels a great affinity with his new home city: both of them were bombed, are full of debris, are rebellious (Rotterdam refuses to resemble a city), lost and will die in oblivion.

Hutka's dominant genre has always been song lyrics. During his exile, he reduced his production rapidly: according to a list on his website, he wrote on average fifteen songs a year between 1966 and 1977, but only three songs a year in exile. Some of the exile songs are humorous, but mostly they capture the bitterness of the life in exile. One of the other topics was the persecution of Czechoslovak dissidents, and later universal subjects such as the forthcoming old age. Hutka's alter ego appears particularly in the lyrics about exile. In regard to music and lyrics, the song "Nizozemí" (The Netherlands, 1983, lyrics by Hutka, music by Jan Stavinoha, another Czech exile writer-musician) stands out among all

20 See Sedláčková 2020 for more information on the position of Jana Beranová in the Dutch literary field. 
the songs. Hutka depicts here his irreconcilable relation to his new home country. Apart from the positive features, such as the civil liberties, it is full of negative motifs, which we can find in other Hutka's works as well: work as the meaning of life (related to Calvinism), boredom, lack of passion, excessive practicality, calculation, liking for kitsch, lack of folk culture, and "uprooted language". These were the main reasons due to which Hutka was not able to form an attachment to the Dutch and their culture.

\section{Landsmann in Dutch exile: discourse}

Ivan Landsmann is the author of five novels; three of them were written in Dutch exile. ${ }^{21}$ In addition, his fourth novel Šestý smysl (The Sixth Sense, 2008) was partly inspired by his Dutch exile.

The novels Pestré vrstvy (finished in June 1986, published in 1999) a Vězení na svobodě (finished in November 1995, published in 2002) originated as Landsmann's private memoirs. When writing them, he did not know he would make it to a respected Czech publishing house. Landsmann's writing was intended mainly as autotherapy: it is strongly autobiographical, and the two last-mentioned novels follow each other chronologically.

Pestré vrstvy consists of two considerably different parts: the first one captures experiences from Landsmann's fifteen-year-long career as a miner, whereas the other part gives a detailed description of the first days and weeks after his emigration (his visit to his brother's place in Canada and idling in Holland). The parts are heterogenous not only as to the setting and characters, but also in style (the first part is full of local dialect and miners' slang, and it has an anecdotal character). Even the protagonist's personality (first-person narrator) changes considerably: in the first part, Ivan the foreman is courageous, resolute, tough and physically active, while the asylum seeker in the second part acts as a lonely, helpless, hesitant and naive loser. Ivan the emigrant relies merely on others: in Canada on his brother, in Holland on everybody he meets (in particular Hutka and the refugee organizations). Hutka, as a Moravian compatriot, adopts him as a small child, and even teaches him basic English. It is surprising that Hutka, so frustrated with his own unsatisfactory language skills, acts as a strict and dutiful teacher in Landsmann's story. Although Hutka liked, for sure, a glass of beer or wine, he also tried to control Landsmann's excessive alcohol consumption. Ivan was absolutely dependent on Jaroslav and Daniela: thanks to their efforts and Škvorecký's testimonial (see above) he got political asylum in 1986.

The novel Vězení na svobodě is a bit more literary as it is not purely a chronological record; it contains several flashbacks and dream passages. The main character, Ivan, is the same as in Pestré vrstvy. The book depicts the main events of Ivan's exile between 1986 and 1995 . He noticed the 1989 revolution only from afar as it did not mean anything for his situation (return to Czechoslovakia was out of the question). The crucial change came later, with obtaining the Dutch citizenship in 1995, after which he was able to go to Czechia in order to visit family and friends.

21 As a matter of interest: Landsmann wrote the books on a typewriter he got from Hutka. The latter had got it as a present from his friend, the writer-dissident Ivan Klíma, just before his emigration to the Netherlands. A typewriter with Czech diacritics was precious when in exile. 
In both novels, the main character's life is marked with similar motifs: isolation, depression, purposeless idling, bohemianism and pubs (his favourite pub was aptly named Café La Bohème), alcohol and smoking, women (short relationships or one-night stands), and occasional fights. He disliked Holland, which he mostly labelled as "boring". His dream destination was Canada because of its nature, which he missed in the Netherlands. Between the lines, though, we can read it was more likely so because he could rely on his brother in Canada to take care of him. There was no one like that in Holland after Hutka returned to Prague. Besides, it is evident that Ivan did not have much understanding towards other immigrants: he spoke derogatorily about Africans. He was not tolerant towards homosexuals either (there are homophobic expressions in the novels). Apart from his contacts in pubs and bars, he showed no effort to assimilate; he also spoke derogatorily about the Dutch classes for immigrants: a kindergarten for adults, attended by sixty-year-old Turkish women (Landsmann 2002: 64), the same opinion as Hutka had. In both novels, Ivan made no efforts to become involved or to get to know Dutch culture (even if it were for free) or to travel around the Netherlands (it is striking that in both novels, Ivan always moved around Rotterdam on foot and never even got a bicycle). It seems, thus, that he complicated his situation on purpose, or did not look for a solution in order to feel even more wronged. Similarly, he complained about being bored or missing the nature (and was jealous of Hutka's travels to the south every summer). The passivity and the grievance of Landsmann's alter ego was even worse than Hutka's.

Hutka emigrated because of the persecution by the secret police, and, for a great part, under the pressure of his wife (later he even declared that it was merely because of his wife, which he did not realize at first, see Hutka in Čermák 150). Landsmann disliked the communists since his childhood, but political motivation was not likely in his case, especially as he was leaving two daughters behind. After his protagonist Ivan encountered his ex-wife again in 1995, he realized that she had always been a hysterical shrew and he always felt so weak and helpless in her presence that only an escape to the West could save him (Landsmann 2002: 249). Landsmann's motivation was probably very prosaic, as Hutka confirmed (Hutka in Čermák: 140). Most likely, it was a combination of personal (unhappy marriage) and economic motives (finding a better job in Canada), and not a political decision. The language barrier, alcoholism, and nearly zero-assimilation were the reasons Landsmann could not, as a writer, reach the Dutch literary field. He succeeded in the Czech field only by luck, thanks to his friendship with Jaroslav Hutka.

\section{Conclusion}

Jaroslav Hutka and Ivan Landsmann can be characterized as two enfants terribles of the Czech cultural exile in the Netherlands.

Hutka fixed his attention too much on his own past and past success. His romantic and stubborn personality did not allow him to truly penetrate the Dutch cultural field: he refused any compromise, adaptation to the taste of the Dutch audience and any commercialization of his work. His position in the Czech immigrant community was complicated by his provocative opinions. The language barrier was another crucial factor. In Dopisy Ivanovi (Letters to Ivan Klíma) he complained about his learning three foreign languages 
without knowing which one to prefer, due to "doubts about the future" (Hutka 2012: 309). Hutka was not able to write without an audience, and therefore, his production stagnated. The West gave him the freedom of speech, but he felt nobody listened to him. He refused to make the content more attractive because he considered it commercialization, equal to kitsch and trafficking. The content then vanished (Hutka 2012: 367). In general, Hutka's alter ego in his various texts (prose, poetry and song lyrics) creates a consistent authorial posture which corresponds with his self-presentation in the media, interviews, photographs etc. Even in the 1980s, Hutka stuck to his hippie image, combined with the image of a romantic poète maudit. He combined features typical for the character of a loner, idealistic dreamer, and Don Quixote on the one hand, and that of a malcontent, rebel and parasite on the other hand. His fascination with his past can be linked to the motif of the fossil, which appeared repeatedly in his work as well as in his exile life.

As opposed to the unappreciated artist Hutka, Landsmann was a real proletarian, alcoholic, outsider and, culturally, a tabula rasa. Despite his tough past as a miner, he led a completely passive life (according to Hutka, like a bag of potatoes), in naivety and complete dependence on others. As a beginning author, he can be characterized as an autotherapist and a natural talent. He was lucky when entering the literary field in that he got to know Hutka, but generally, his posture was formed rather through his failures and lifelong bad luck, together with his tendency to blame the others (his father, wife, brother in Canada). In addition, his personal stances correspond with his literary alter ego. His autobiographical fiction was created spontaneously and with a great dose of authenticity, as he had no audience to accommodate to. For instance, he felt free to let his alter ego use a dialect, a slang, vulgarisms and make homophobic, sexist or racist utterances. He had no chance of entering the Dutch literary field, as he did not speak any western language well (and he did not try to, either), and he had no contact with the literary scene, except for Hutka. He was unlikely to succeed in the Netherlands, because his success in Czechia was based on his inimitable style: a combination of miners' jargon and a North-Moravian dialect. As to the literary qualities, his texts were rather below average.

Generally speaking, it was Hutka who fitted better the notion of an exilic posture, although he was not its prototype either. For the Dutch, he often played the role of "a refugee from the East" at various cultural events and in the media, but he never became a real Czech cultural ambassador or a mediator between two cultures since he was a fierce critic of both the Czech and the Dutch culture and mentality. ${ }^{22}$

\section{BIBLIOGRAPHY}

Bongers, Willem. De verteller van de waarheid. Aspecten van Kader Abdolahs posture (1993-2011). MA thesis. Utrecht: Universiteit Utrecht, 2011.

Bossaert, Benjamin. No nation without representation: Heroes going places. A comparative research of Flemish and Slovak heroes in literature. Diss. Olomouc: Univerzita Palackého, 2020.

Bourdieu, Pierre. Outline of a Theory of Practice. Transl. by Richard Nice. Cambridge University Press, 1977.

22 This work was supported by the European Regional Development Fund project "Creativity and Adaptability as Conditions of the Success of Europe in an Interrelated World" (reg. no.: CZ.02.1.01/0.0/0.0 /16_019/0000734). 
Bourdieu, Pierre. Pravidla umění. Geneze a struktura literárního pole. Transl. by Petr Kyloušek and Petr Dytrt [Les Règles de l'art. Genèse et structure du champ littéraire]. Brno: Host, 2010.

Čermák, Miloš. Pravděpodobné vzdálenosti. Rozhovor Miloše Čermáka s Jaroslavem Hutkou. Praha: Academia, 1994.

De Jong, Hendrik. “Protestzanger in Kafka-land.” De Volkskrant 15 Oct. 1982: 17.

De Jong, Hendrik. "Waar is de hemel, waar is Praag?" De Volkskrant 9 Nov. 1984: 20.

Delpher. www.delpher.nl. 31 Mar 2021.

Dorleijn, Gillis J. "De muzikale verwijzing als positioneringsmiddel." Nederlandse Letterkunde 12.4 (2007): 241-254.

Dorleijn, Gillis J., Ralf Grüttemeier and Liesbeth Korthals Altes (eds.). Authorship Revisited. Conceptions of Authorship around 1900 and 2000. Leuven - Paris - Walpole: Peeters, 2010.

Dynarowicz, Eva. "A Migrant Writer's Manifesto. Kader Abdolah as a Public Intellectual." Dutch Crossing. Journal of Low Countries Studies 42.1 (2018): 77-95.

Goldmann, Jakub. "Ivan Landsmann: De Niro asi taky nekouká na svoje filmy." Lógr 20. Magazín pro moderní kulturu. Praha: Lógr z.s., 2016. 6-11.

Ham, Laurens. Door Prometheus geboeid. De autonomie en autoriteit van de moderne Nederlandse auteur. Hilversum: Verloren, 2015.

"Ivan Landsmann." Pamét národa. https://www.pametnaroda.cz/cs/landsmann-ivan-1949. 31 Mar. 2021.

"Jaroslav Hutka." Pamět národa. https://www.pametnaroda.cz/cs/hutka-jaroslav-1947. 31 Mar. 2021.

Hutka. www.hutka.cz. 31 Mar. 2021.

Hutka, Jaroslav. Požár v bazaru. Fejetony z let 1977-1989. Praha: M. Šlahounek, 1990.

Hutka, Jaroslav. Fejetony. Praha: Galén, 2009.

Hutka, Jaroslav. Prózy II. Praha: Galén, 2012.

Hutka, Jaroslav. Koryta krve. Praha: Mladá fronta, 1996.

Jeensma, Jelle and Pim Wiersinga. "Jaroslav Hutka. Verhaal van een schipbreukeling." Trouw 17 Aug. 1989: 16.

"Krajané v Nizozemsku." Czech Ministry of Foreign Affairs. https://www.mzv.cz/file/1556132/Krajane _v_Nizozemsku.doc. 29 Mar. 2021.

"Kritiek Charta op optreden Nederlandse journalisten in Praag." NRC Handelsblad 27 Oct. 1978: 3.

"Kritiek Charta-leden op optreden NVJ-delegatie." Trouw 28 Oct. 1978: 3.

Landsmann, Ivan. Pestré vrstvy. Praha: Torst, 1999.

Landsmann, Ivan. Vězení na svobodè. Praha: Torst, 2002.

Landsmann, Ivan. Šestý smysl. Praha: Nakladatelství XYZ, 2008.

"Liedjeszanger Jaroslav Hutka: 'Leven in Oosten of Westen? Mensen zijn de besten!'” Het vrije volk 27 Dec. 1980: 3.

Meizoz, Jérôme. "Modern Posterities of Posture. Jean-Jacques Rousseau." Authorship Revisited. Conceptions of Authorship around 1900 and 2000. Eds. Gillis J. Dorleijn, Ralf Grüttemeier and Liesbeth Korthals Altes. Leuven - Paris - Walpole: Peeters, 2010. 81-93.

Middelburg, Bart. “Zanger Hutka: 'Dubcek geen held, maar laffe beraucraat.” Het Parool 20 Aug. 1988: 6.

Mulder, Hans. “Jaroslav Hutka’s Hollands oponthoud.” NRC Handelsblad 11 Jan. 1991: 16.

"Open brief: oppositie genegeerd. Kritiek Tsjechen op reis journalisten." Het Parool 27 Oct. 1978: 3.

Praagse Lente - Pražské jaro Revisited 68. Praha/Litomyšl: Paseka, 2008.

Rovers, Daniël. "Figuurauteur versus auteursfiguur. Tonnus Oosterhoff - een casestudy." Nederlandse Letterkunde 13.3 (2008): 204-224.

Rovers, Daniël. De figuur in het tapijt. Op zoek naar zes auteurs. Amsterdam: Wereldbibliotheek, 2012.

Salomonson, An. "Praagse zanger kiest vrijheid in Nederland.” NRC Handelsblad 1 Nov. 1978: 3.

Sedláčková, Lucie. "Tsjechische ballingschrijvers in Nederland: de positie van Jana Beranová en Jan Stavinoha in het literaire veld." Roczniki humanistyczne 68.5 (2020): 37-51.

Šebek, Josef. Literatura a sociálno. Bourdieu, Williams a jejich pokračovatelé. Praha: Filozofická fakulta Univerzity Karlovy, 2019.

Štráfeldová, Milena. “Adaptace v exilu je dlouhý proces, ř́ká psycholog Jiř́i Diamant z Nizozemí." 20 Sep. 2008. Český rozhlas. https://cesky.radio.cz/adaptace-v-exilu-je-dlouhy-proces-rika-psycholog-jiri -diamant-z-nizozemi-8591937. 10 Mar. 2021.

Thomassen, Michel. "Eens Tsjech, altijd een Tsjech." Algemeen Dagblad 2 Dec. 1989: 49. 
“Tsjechische kunstenaars vervolgd”. De Volkskrant 18 Nov. 1977: 11.

“Tsjechen kritiseren Journalistenbond." De Volkskrant 28 Oct. 1978: 21.

Van Boven, Erica and Pieter Verstraten (eds.): Schrijverstypen. De moderne auteur tussen individu en collectief. Hilversum: Verloren, 2016.

Van Veen, Simone. “Jaroslav Hutka's behoefte aan de Nederlandse taal." Het Parool 3 Nov. 1984: 7.

Van Voorst, Sandra. "De ballingschrijver Kader Abdolah." Schrijverstypen. De moderne auteur tussen individu en collectief. Eds. Erica van Boven and Pieter Verstraeten. Hilversum: Verloren, 2016. 203-216.

Verhulst, Trix. "Eerste Nederlandse plaat van Tsjechoslowaak Jaroslav Hutka: 'Hier is mijn thuis'." Het vrije volk 22 Nov. 1984: 21.

Lucie Sedláčková

Charles University in Prague

lucie.sedlackova@ff.cuni.cz 